Martina Topić

Leeds Business School

Leeds Beckett University

562 Rose Bowl, Portland Crescent

LS1 3HB Leeds

United Kingdom

\title{
M.Topic@leedsbeckett.ac.uk
}

$\underline{\text { www.martinatopic.com }}$

LinkedIn: https://uk.linkedin.com/in/dr-martina-topi\%C4\%87-fhea-22b0155

Twitter:@martina_topic

ORCID: https://orcid.org/0000-0002-5894-2979

This work was supported by the British Academy research grant under SRG18R1\181033

\section{'It's something that you should go to HR about' - Banter, Social Interactions and Career Barriers for Women in the Advertising Industry in England}

\section{Purpose}

This paper uses a Difference Approach and Bourdieu's habitus theory to analyse the experiences of women working in the advertising industry with a particular focus on employee relations such as social interactions in advertising offices, banter and career barriers.

\section{Design/methodology/approach}

Thirty-eight qualitative interviews were conducted with women from the advertising industry in England, exploring both the employee and managerial perspectives on social interactions. Women were asked about their office culture, including networking expectations, dress code, 
banter, social interactions, and potential career barriers such as exclusion from business decisions and having to work harder to succeed. Thematic analysis has been used to analyse data.

\section{Findings}

Thematic analysis revealed two themes, patriarchal culture in advertising offices and gendered social interactions and banter. Women believe they are excluded from business decisions and perceive career barriers in office culture grounded in masculine banter and masculine social interactions. Similar themes emerged regardless of women's length of experience or role within the organisation suggesting a problem with the masculine work culture in the advertising industry in England. Besides, women tend to prefer different social interactions to men, but find masculine interactions domineering advertising offices.

\section{Practical Implications}

Employers should consider implementing new internal policies on communication and behaviour in offices to create a more inclusive and respectful culture. More consciousnessraising is needed to make women aware that inequality is more than just a pay gap and glass ceiling, but also the structure of the organisation and the office culture.

\section{Social Implications}

The paper contributes towards a better understanding of the impact of social interactions in the office on the work culture with a case study from the advertising industry. The paper points towards differences in communication and social interactions between men and women and the fact the masculine form of social interactions and banter dominate advertising offices.

\section{Originality/value}

To the best of author's knowledge, this is the first paper tackling office culture in the advertising industry in England using the Difference Approach and Bourdieu's habitus theory. Keywords: women, office culture, social interactions, banter, Difference Approach, habitus 


\section{Introduction}

Despite improvements, it has been evidenced that when it comes to the communications industry (advertising, public relations, journalism) women outnumbered men decades ago, however, they are still paid less than men, find career progression more difficult, and often report discrimination, sexism and career barriers (Topić, 2020; CIPR, 2019; Cooke, 2019; Place \& Vaderman-Winter, 2018; Topić, 2018; Crewe \& Wang, 2018). In advertising, in particular, gender stereotypes remain a norm because of which the UK in 2019 introduced bans on sexist stereotypes in advertising (Sweney, 2019) and even though women form the majority of the workforce they are still underrepresented in managerial positions (Sleeman, 2019; UK Digital and Creative Sector Talent Insight Report, 2017; IPA Agency Census, 2019; Stein, 2017). The situation in the communications industry is on par with other professions where women also face exclusions, lower salaries and slower career progress than men (Santos \& Garibaldi de Hilal, 2018) whilst motherhood frequently causes problems with career progressions (Grow \& Yang, 2018).

One of the reasons for this situation often lies in masculine norms, which are built into organisational structures and require women to embrace masculine identities (Lewis, 2014; Topić, 2018; 2020; Kemp, 2016). For example, in 2005, Neil French, a copywriter stated that the work of women "in creative departments is 'crap ... and they don't make it to the top because they don't deserve to"' (Sampey \& O'Leary, 2005, n. p., cited from Broyles \& Grow, 2008, p. 1). In 2016, the chairman of Saatchi \& Saatchi caused fury when he said that women in advertising do not face discrimination but their own inertia and lack of ambition (Davies \& Jackson, 2016). Grow and Yang (2018) added that the advertising industry is slow to change. For example, creative departments are still staffed by male creative directors and this brings 
about the old-boys mentality or (homo)sociality (Broyles \& Grow, 2008; 2010; Crewe \& Wang, 2018). Nixon (2013) argued that 'homosociability' was redefined in a new millennium by blurring differences in visual styles between straight and gay men, however, advertising industry remains centred on masculinity represented in sports, cars, girls and booze. Whilst Nixon's (2013) study shows that gay men reported that the distinction between straight and gay men has been blurred when re-defining masculinity, the masculine expectations remained, thus leaving women behind. Windels and Lee (2012) and Grow and Broyles (2011), argued that despite women representing a large part of the advertising workforce, their numbers are still low in the highest positions (including creative floors, as very prestigious roles in advertising) despite women influencing $85 \%$ of decisions on purchases. Windels and Lee (2012) thus argue that the "norms and expectations of the creative department have been constructed based on a masculine paradigm, which can serve as an impediment to women's access to senior peers, noteworthy assignments, and ultimately, their creative success as they perform based on a male model" (p. 503). This then leads to a situation that women's work can be labelled as 'crap' as shown above, and this is because it is men who judge work, and in a competitive environment where creative teams compete with each other within the same agency, this often leaves women out as their work is not judged as worthy by senior men (ibid). Nevertheless, Grow and Broyles (2011) argued that women creatives often have to erase their femaleness to get ahead in their careers, an issue already recognised in advertising and media studies (North, 2009; Mills, 2014; 2017; Topić, 2018; 2020).

In the UK's advertising industry long working hours and networking with clients after work is seen as a professional norm and this requirement has historically impacted women's career progression (McLeod, 2011; Gill, 2014; Crewe \& Wang, 2018). Besides, organisational culture in the advertising industry is often seen as a place for young people and for senior people who 
do not have family responsibilities (Clare, 2013; Jarvis \& Pratt, 2006; Grabher, 2004). Some studies have also recognized issues with "(homo)sociality and space” (Crewe \& Wang, 2018, p. 12) in which there are men on top who work "within a patriarchal gender order", and this practice includes "homo-sociality as formal and informal means of communication, including male networking, bonding, joking and dress codes" (ibid, p. 13). This formal and informal communication can happen deliberately or spontaneously in offices, during lunchtime and even in toilets (Gregory, 2009). This means that there is something like an 'old boys' networks in the advertising industry, which naturally constructs hierarchies and affects promotions (ibid). In a recent study on women in advertising in England, Topić (2020) found that women face career barriers, sexism and sexual harassment and that the advertising industry as a whole can be seen as masculine habitus where only women who embrace masculine characteristics and become 'blokish' succeed.

Against the debate in the literature above, this paper analyses the employee relations in the advertising industry in England, specifically by looking at banter, social interactions and career obstacles in advertising offices using the Difference Approach and thus explores employee relations and the office culture, which is an unexplored area in the advertising research. The main aims of the paper were to explore whether social interactions and communication in the office contribute towards masculine office culture and barriers women face in the advertising industry in England and whether women prefer different social interactions to men. With this, the paper explores whether the advertising industry has structural barriers and thus functions as a masculine habitus.

\section{Theoretical Framework and the Method}


The approach of this study was to explore how women working in advertising experience their office culture and social interactions that happen in offices (e.g. banter, chatting with colleagues) as well as to explore whether their views suggest that the office culture is potentially hindering women's career progressions, or that norms in the office are oppressing women who work in the advertising industry. The study also looked to what extent women engage in social interactions differently than men.

This focus of the research is underpinned by the Difference Approach to studying women and Bourdieu's (2007) habitus theory. The Difference Approach emerged from radical feminism and has been used to argue that women and men are different and have different interests and communicate and lead differently, with exceptions on both sides. For example, women are seen to have different communication skills such as conversational patterns based on relationship building and supportiveness as opposed to dominance and interruptions ascribed to men (West \& Zimmerman, 1983; Tannen, 1990; Merchant, 2012). These differences in communication are often a result of the socialisation process where girls tend to interact and talk in smaller groups whereas boys are more encouraged to report information and compete, which then leads to women being more committed to networking and relationship-building whereas men express independence and hierarchy (Maltz \& Borker, 1982; Tannen, 1986; 1990; 1995; Yule, 2006). These communication differences have an impact on leadership as well as gender relations in the workplace where women progress harder and face obstacles (Merchant, 2012; Vukoičić, 2013). Therefore, women were asked questions on their office culture such as banter and differences between genders, dress code, who they talk to in the office, what they talk about, networking expectations, whether they ever faced exclusion from business decisions and whether they feel they had to work harder to get promoted. The latter question was asked of women who hold a managerial position. 
Bourdieu's (2007) concept of habitus explains social norms and the way they get embedded in the society, which means that individuals rarely challenge injustice or oppression because inequality is embodied to the system to an extent that women fail to recognise inequality due to processes and practices being an everyday thing (Bourdieu and Wacquant, 1992; Bourdieu, 2007; Chambers, 2005). Bourdieu (2007) nevertheless argued that inequality perpetuates itself through everyday practices to the point this inequality becomes "acceptable and even natural" and this practice can be seen as "symbolic violence, a gentle violence, imperceptible and invisible even to its victims" (p. 1). Therefore, societies work as masculine habitus grounded in "arbitrary division which underlines both reality and the representation of reality" (ibid, p. 3). Therefore, "we have embodied the historical structures of the masculine order in the form of unconscious schemes of perception and appreciation" (Bourdieu, 2007, p. 5), and this is because mechanisms of domination are incorporated into daily realities so the social order functions as "an immense symbolic machine tending to ratify the masculine domination on which it is founded: it is the sexual division of labour, a very strict distribution of the activities assigned to each sex, of their place, time and instruments; it is the structure of space, with the opposition between the place of assembly or the market, reserved for men, and the house, reserved for women" (Bourdieu, 2007, p. 9-11). This approach was deemed as useful for this study because the Difference Approach, from one point, shows that the majority of women do things differently, in large part a result of the socialisation process, which is gendered for boys and girls. However, habitus approach shows that this is how the social order works and that because of it many women fail to notice oppression and have a tendency to even outline masculine practices as those that women need to succeed without realising this is a form of oppression (Bourdieu and Wacquant, 1992; Bourdieu, 2007; Chambers, 2005). For example, in a recent study on women in advertising in England, Topić (2020) found that women 
emphasise masculine characteristics as those one should have to succeed in advertising, and thus argues that women have to be 'blokish' and embrace cultural masculinity to succeed, which is not something that comes naturally to women due to the socialisation process.

In terms of conceptualising the study, the following concepts were particularly useful,

a) From the Difference Approach, the assumption was taken that women engage in social interactions and banter differently than men, and thus women were asked questions on these two concepts to explore whether women will report that they engage in social interactions and banter differently than men.

b) From the habitus theory, two concepts were particularly useful, i.e. unconscious acceptance of the social order with which the research explores whether those who do not fit into practice, that can be seen as cultural masculinity, face inequality.

Cultural masculinity is understood as a practice that comes naturally to men rather than women because of the socialisation process, and this would include behaviour and communication that would be seen as inherently masculine (Alvesson, 1998; 2013), in the case of this study, this would be being able to join masculine banter and engage in interactions with men. Bourdieu (2007) argued that women face dual requirements because, from the one point, they have to be the right candidate for the job, but from the other, they also have to demonstrate characteristics that come naturally to men due to the socialisation process, such as "a physical stature, a voice, or dispositions such as aggressiveness, self-assurance, 'role distance', what is called natural authority etc., for which men have been tacitly prepared and trained as men" (p. 62, emphasis in the original). In this paper, this observation is then also applied to social interactions and banter in an attempt to explore whether women report that they socially interact differently and whether they feel this is taking them back because they cannot get ahead. With this, the paper 
also draws from studies in advertising that show that women often have to hide their femaleness to succeed (Grow \& Broyles, 2011) or become 'blokish’ to succeed (Mills, 2014; 2017; Topić, 2018; 2020; North, 2009). However, whilst the majority of works concentrate on women creatives, this study also explores women in account handling, marketing, media, business development, planning, owners/directors and design, thus exploring whether there is a structural inequality that runs across departments in the advertising industry.

The question of exclusion from business decisions is directly linked to the notion of power, and the paper also discusses who has the true power in organisations. Power was recognised as a feminist issue in early works such as the work of French (1985) who defined power as "the process of the dynamic interaction. To have power means having access to the network of relations in which an individual can influence, threaten, or persuade others to do what he wants or what he needs (...) The individual has no power. It is awarded by a large number of other people to the one that dominates and such allocation is irrevocable" (p. 509; see also Vukoičić, 2013). Besides, Disch and Hawkesworth (2016) argued that power should be defined as 'power over' and this is a situation where men have power over women in many different ways, which includes marginalisation, denying autonomy to women, violence, hegemonic masculinity, and economic exploitation. However, some feminists also argued that male domination is pervasive and that female power is a contradiction in terms (French, 1985; MacKinnon, 1989; Pateman, 1988). Finally, the question of having to work harder to succeed is linked to both power and masculine culture.

A total of 41 semi-structured interviews was conducted with women from London, Leeds, Manchester, Liverpool, Newcastle, Reading, Edinburgh, Cardiff, Belfast, one small place in the south of England and one small place in Yorkshire (anonymised due to ethics requirements) 
between December 2018 and May 2019. However, out of 41 interviewed women, 38 were from England due to the impossibility to obtain any further interviews from other UK countries, and views quoted in the findings section resemble experiences from 38 women from England. Of those, 21 were based in the south of England (19 in London) and 17 were based in the north of England. Also, 18 interviewees were employees without managerial duties whilst 20 were managers. Interviewees were recruited through LinkedIn and one interviewee was a former student of the author. Interviewees were identified using the IPA website. Each agency member was searched and each person identified on the website was then manually searched on LinkedIn since agency websites rarely have staff's email address. IPA website and agency members were deemed as relevant for agency search since IPA agencies hold $85 \%$ of all advertising work awarded in the UK (IPA website, n.d.).

The work experience of interviewees ranges from one month in the industry to 34 years. Interviews were conducted face-to-face (4) and via telephone (34). Of 38 interviewees, seven work in the in-house advertising department (in larger companies that have their advertising and marketing departments and do not commission agencies to do promotional work), and 31 works in an advertising agency. Since job titles are distinctive and interviewees have different titles even though they do the same job in many cases, and to preserve confidentiality their roles are grouped into creative (including art directors), account handling, marketing, owner/director/partner, media, design, planning and business development (table 1).

Table 1. Interviewee's data

\begin{tabular}{|l|l|l|l|l|l|l|}
\hline $\begin{array}{l}\text { Interviewee } \\
\text { no. }\end{array}$ & Department & $\begin{array}{l}\text { Type of } \\
\text { company }\end{array}$ & $\begin{array}{l}\text { Years of } \\
\text { experience }\end{array}$ & $\begin{array}{l}\text { Employee } \\
\text { manager }\end{array}$ & Location & Comments \\
\hline 1 & Creative & Agency & 30 & Owner/manager & $\begin{array}{l}\text { A small place } \\
\text { in Yorkshire }\end{array}$ & $\begin{array}{l}\text { Anonymised } \\
\text { for } \\
\text { confidentiality }\end{array}$ \\
\hline 2 & Creative & In-house & 2.5 & Manager & London & \\
\hline 3 & $\begin{array}{l}\text { Account } \\
\text { handling }\end{array}$ & In-house & 1 month & Employee & Leeds & \\
\hline 4 & Marketing & Agency & 4 & Employee & Manchester & \\
\hline 5 & Owner & Agency & 34 & Manager & Manchester & \\
\hline 6 & Media & Agency & 4 & Employee & Leeds & \\
\hline 7 & Designer & In-house & 1.5 & Employee & London & \\
\hline
\end{tabular}




\begin{tabular}{|c|c|c|c|c|c|c|}
\hline 8 & Marketing & Agency & 7 & Manager & London & \\
\hline 9 & Creative & Agency & 5 & Employee & London & \\
\hline 10 & $\begin{array}{l}\text { Business } \\
\text { development }\end{array}$ & Agency & 12 & Manager & London & \\
\hline 11 & $\begin{array}{l}\text { Account } \\
\text { handling }\end{array}$ & In-house & 3 & Manager & Liverpool & \\
\hline 12 & Director & Agency & 14 & Manager & Belfast & $\begin{array}{l}\text { Removed } \\
\text { from the } \\
\text { dataset due to } \\
\text { low sample }\end{array}$ \\
\hline 13 & Media & Agency & 27 & Employee & Newcastle & \\
\hline 14 & Creative & Agency & 18 & Manager & London & \\
\hline 15 & Marketing & In-house & 20 & Manager & Leeds & \\
\hline 16 & Creative & Agency & 19 & Manager & London & \\
\hline 17 & $\begin{array}{l}\text { Account } \\
\text { handling }\end{array}$ & In-house & 25 & Employee & Leeds & \\
\hline 18 & $\begin{array}{l}\text { Account } \\
\text { handling }\end{array}$ & Agency & 6 months & Employee & Manchester & \\
\hline 19 & Creative & Agency & 17 & Manager & Leeds & \\
\hline 20 & $\begin{array}{l}\text { Account } \\
\text { handling }\end{array}$ & Agency & 4 & Employee & London & \\
\hline 21 & Media & Agency & 30 & Employee & London & \\
\hline 22 & Partner & Agency & 20 & Manager & Edinburgh & ibid \\
\hline 23 & Media & Agency & 5 & Employee & Newcastle & \\
\hline 24 & Media & Agency & 3 & Manager & London & \\
\hline 25 & Media & Agency & 18 & Manager & London & \\
\hline 26 & Director & Agency & 15 & Manager & Newcastle & \\
\hline 27 & Planning & Agency & 20 & Manager & London & \\
\hline 28 & $\begin{array}{l}\text { Account } \\
\text { handling }\end{array}$ & Agency & 9 months & Employee & Cardiff & ibid \\
\hline 29 & $\begin{array}{l}\text { Account } \\
\text { handling }\end{array}$ & Agency & 12 & Manager & London & \\
\hline 30 & $\begin{array}{l}\text { Account } \\
\text { handling }\end{array}$ & Agency & 12 & Employee & London & \\
\hline 31 & Planning & Agency & 5 & Employee & London & \\
\hline 32 & Media & Agency & 7 months & Employee & Leeds & \\
\hline 33 & $\begin{array}{l}\text { Business } \\
\text { development }\end{array}$ & Agency & 4 & Employee & $\begin{array}{l}\text { Small place in } \\
\text { the south of } \\
\text { England }\end{array}$ & $\begin{array}{l}\text { Anonymised } \\
\text { for } \\
\text { confidentiality }\end{array}$ \\
\hline 34 & $\begin{array}{l}\text { Account } \\
\text { handling }\end{array}$ & Agency & 22 & Employee & Reading & \\
\hline 35 & Media & Agency & 5 & Manager & Leeds & \\
\hline 36 & Director & Agency & 22 & Manager & London & \\
\hline 37 & Marketing & In-house & 8 months & Employee & London & \\
\hline 38 & $\begin{array}{l}\text { Account } \\
\text { handling }\end{array}$ & Agency & 5 & Employee & London & \\
\hline 39 & Director & Agency & 19 & Manager & Manchester & \\
\hline 40 & Creative & Agency & 19 & Manager & London & \\
\hline 41 & $\begin{array}{l}\text { Account } \\
\text { handling }\end{array}$ & Agency & 11 & Manager & Leeds & \\
\hline
\end{tabular}

The interviews were semi-structured and lasted approximately 30 minutes each. After completion of the interviewing process, all interviews were transcribed for the analysis. Qualitative research usually takes a 'lifeworld' approach (Kvale \& Brinkmann, 2009) and uses samples of up to 25 interviewees to obtain a rich understanding of the problem (Creswell, 2007). However, in this study, the sample has been extended to capture views between employees and managers and regional differences. As there is no intention to generalise the 
findings, this sample is more than enough to provide a feminist analysis of views of women working in the advertising industry in England.

Coding approach of Morse and Richards (2002) was used. This means that open coding was done first to identify themes emerging from data, and axial coding helped with analysing data against different sections of data to explore a link between identified concepts. Selective coding helped in capturing relevant themes. After that, a thematic analysis has been conducted using the approach from Braun and Clarke (2006) where findings are visualised in a thematic graph and the analysis is supported with direct statements. Thematic analysis is "a systematic approach to the analysis of qualitative data that involves identifying themes or patterns of cultural meaning; coding and classifying data, usually textual, according to themes; and interpreting the resulting thematic structures by seeking commonalities, relationships, overarching patterns, theoretical constructs, or explanatory principles” (Lapadat 2010, p. 926). It is essentially a sensemaking approach, which was convenient for this study due to the fact this was the first study on office culture in the advertising industry using the Difference Approach and the Bourdieu's habitus theory.

The research questions of the study were,

- Are women engaging in social interactions differently than men?

- Are social interactions at work centred on masculine norms?

- Can social interactions and banter in advertising offices be seen as masculine habitus?

Studying social interactions by using the Difference Approach and the habitus theory is a largely unexplored field and the approach has relevance for understanding contemporary organisations since social rules have been set around masculine values and feminists argued 
that the oppression of women is embedded in every aspect of the society (Jaggar \& Rothenberg, 1994; Daymon \& Demetrious, 2010; Rakow \& Nastasia, 2009). In organisational studies, feminists have denounced bureaucracy and hierarchy in organisations as "male-created and male-dominated structures of control that oppress women" (Acker, 1990, p. 141). Saval (2015) argued that historically women have had to take up low paid office jobs and that women office workers were historically treated as office wives by senior men, and ability to attend to boss's needs was seen as more relevant than a stenographic skill, for example.

MacKinnon (1989) argued that "inequality comes first, differences come after" (p. 219), thus suggesting that inequality is justified with differences rather than differences causing inequality. Radical feminists, for example, historically argued for raising consciousness to enlighten women about all forms of oppression they face. Founders of Redstockings radical feminist group wrote in their manifesto that "chief task at present is to develop a female class consciousness through sharing experience and publicly exposing the sexist foundation of all our institutions. Consciousness-raising ... is the only method by which we can ensure that our program for liberation is based on the concrete realities of our lives" (Chambers, 2005, p. 336).

The research has obtained approval from the local research ethics coordinator, and to ensure anonymity, and in line with ethics policy of the University, interviewees are quoted anonymously using 'interviewee 1', etc.

\section{Findings}

The analysis of interviews suggests that there are no dress code expectations except the smart dress code for meetings with clients (e.g. a suit), which applies to both men and women, otherwise, the office culture is relaxed. Therefore, it does not seem as if advertising 
organisations impose patriarchal expectations on women and the way they are supposed to present themselves. Besides, interviewees reported networking expectations as more relevant for big agencies in London, which signals that some things may be changing in the advertising industry, at least outside of London, which echoes findings from recent literature on networking as a job requirement predominantly in London (Crewe \& Wang, 2018; Topić, 2020). What is relevant is that there are no meaningful differences in responses from interviewees in regards to areas of their work (e.g. creative, account handling, planning, media, etc) as all women tend to report issues with masculinities, and there are no meaningful differences between employees and managers, the latter signalling tokenism or a situation in which women are put in the position of power but lack the real power to make decisions and influence departments (Kanter, 1977; Simpson, 1997; Acker, 1990; MacKinnon, 1989; Hemming, 1985).

Two main themes run through the responses from interviewees. It appears that advertising offices have a patriarchal culture and that social interactions and banter are gendered. Thus, the following thematic graph has been developed, based on responses from interviewees,

\section{Graph 1. Thematic Analysis}




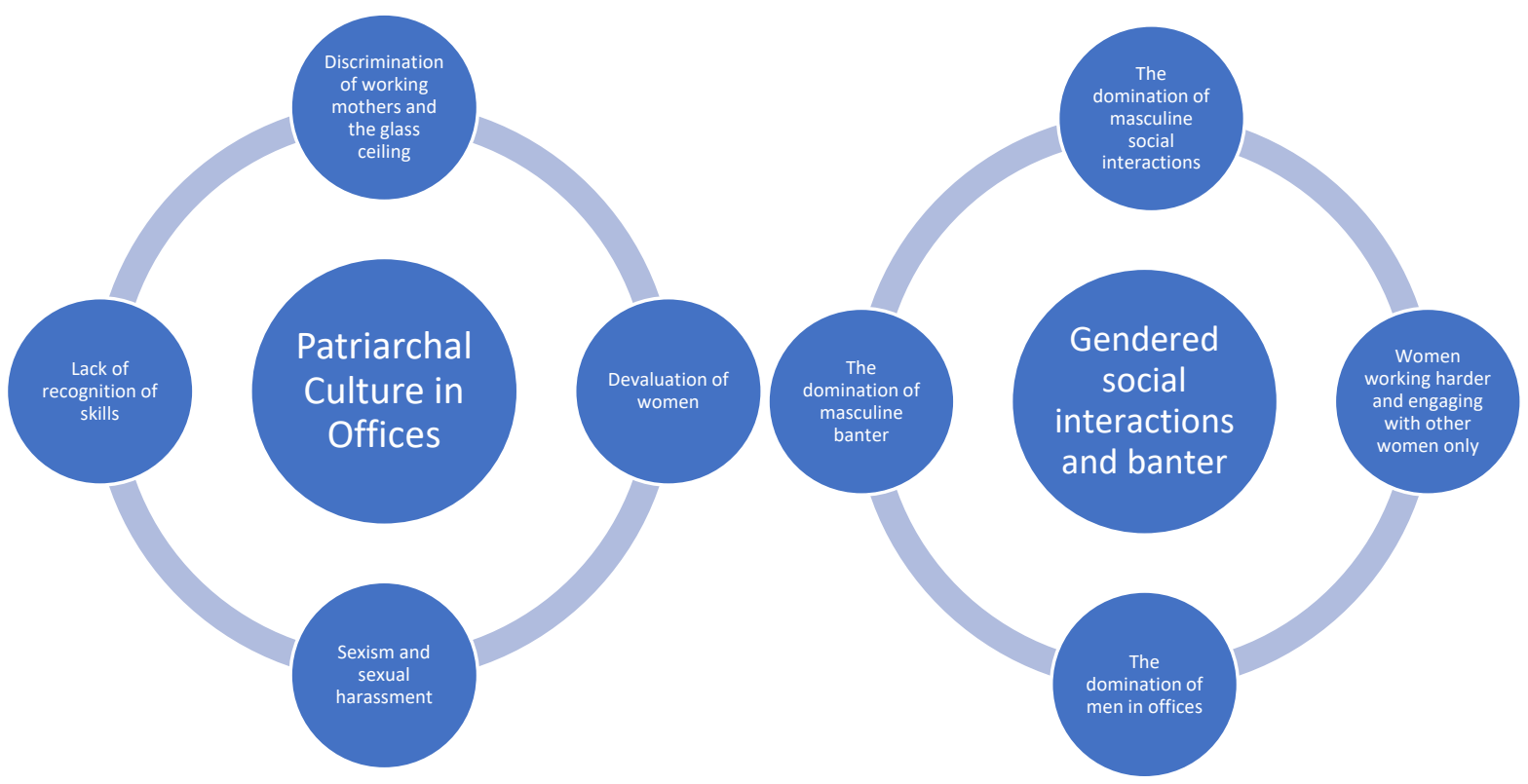

However, interviewed women reported patriarchal culture in their offices such as exclusion from business decisions and not being taken seriously, which signals devaluation of women and patriarchal office culture. For example, some felt they are not being "listened to enough" even though they were "the expert in the room" (Interviewee 4, Manchester, employee). On the other hand, some women had the experience of not being taken seriously and being asked to do "menial and irrelevant stuff such as faxing papers and cleaning up boss' mess" (Interviewee 5, Manchester, manager), which echoes early experiences of women joining offices during the 1920s and the 1930s when women's skills were also devalued (Saval, 2015). Some women also had to leave their jobs because of exclusion even though they were the ones that were supposed to make the decision or they felt excluded for being mothers, which resonates with feminist writings on women being oppressed because of their reproductive capabilities and thus placed into the position of the birth giver and in the private sphere (Templin, 1999; Grow \& Yang, 2018). Bourdieu (2007) calls this situation the "constancy of habitus" (p. 95) because "at each level, despite the effects of hyper-selection, the formal 
equality between men and women tends to disguise the fact that, other things being equal, women always occupy less favoured positions" (p. 92). This situation is further exacerbated with some women reporting not being included in decisions even when on senior positions or not being taken seriously because of being mothers. For example,

\footnotetext{
“So in the past 12 months, I've had to make redundancies and TUPE'd a lot of my staff over into another client and I haven't always had control over that process and also my opinion and my wishes and my decisions have often been ignored or overturned, sometimes for the right reasons, sometimes for, in my opinion, the wrong reasons" (Interviewee 41, Leeds, manager)
}

The fact women were not taken seriously because of being mothers or they are in the position of power but not in control resonates with feminist theory that argues that women cannot hold power because power is meant to be used to dominate, which is fundamentally a masculine characteristic (French, 1985; MacKinnon, 1989; Pateman, 1988). Therefore, women who are in senior positions but still excluded from the business decision can be seen as holding perceived power and as tokens (Kanter, 1977; Simpson, 1997; Acker, 1990; MacKinnon, 1989; Hemming, 1985). This also echoes Bourdieu's (2007) argument on expected behaviour, i.e. “if they behave like men, they risk losing the obligatory attributes of 'femininity' and call into question the natural right of men to the position of power; if they behave like women, they appear incapable and unfit for the job" (p. 67-68). The Difference Approach recognises that part of the reason for women's oppression in work lies in the fact men and women are often different and have different interests, with exceptions on both sides, and this comes as a result of the socialisation in what Bourdieu (2007) calls masculine habitus. Therefore, some women simply cannot embrace the masculine characteristics of behaving and communicating as men do, which then often makes them fall off the ladder (Tannen, 1986; 1990; 1995; Yule, 2006; Topić, 2018; 2020). In this case study, the majority of interviewees stated that there is a 
difference in the way banter works between men and women, which resonates with the Difference Approach that argues women and men have different interests (Tannen, 1986; 1990; 1995; Yule, 2006; Vukoičić, 2013; Merchant, 2012). However, the opinion on banter varies, and thus one woman said that in an all-male environment jokes and office banter are more male-oriented (Interviewee 1, Yorkshire, manager), whereas another woman said that because in her office there are only two women and lots of men, the banter is more male-oriented and she feels that women are working harder and not engaging in any jokes (Interviewee 2, London, manager). This signals that organisations are still a masculine world and echoes an observation from North (2009) who stated that men are not part of the work culture, but rather constitute one.

However, in some cases, male managers tend to make fun of women's affairs such as the \#metoo movement. For example, one interviewee said that this banter was incorporated in a larger jokey culture in the office but she felt that "the jokes maybe go a little bit far" (Interviewee 8, London, manager), which corresponds with the view of another interviewee who said that "women are more considerate" whilst men sometimes "just say whatever they want to say" (Interviewee 10, London, manager). This also corresponds with Bourdieu's (2007) argument on sexual domination because Bourdieu (2007) argued that sexual domination does not always involve sexual advances but can be seen as sexism because "faced with men's sexual jokes, women often have no other choice than to exclude themselves or participate, at least passively, in order to try to integrate themselves, but then running the risk of no longer being able to protest if they are victims of sexism or sexual harassment" (p. 68).

Interviewees in offices with more men often mentioned that men's humour is somewhat vulgar and very direct (interviewee 26, Newcastle, manager). Interviewee 29 said that there is a big 
football culture in her office and that "there is still, unfortunately, a bit of a bias against women and joking around, which still does exist and has existed for 12 years and will exist for many more years I imagine" (London, manager). This view resonates with the view of interviewees who reported the masculine culture and sexism in offices,

“...a lot of it was about either news that was going on in Manchester or there was a lot of talk of women (...) but there was a lot of... so sexualising women, for example, there was a lot of that going on. Office lad banter (...) It was mostly... yes, it was more the men, more the guys. More the senior positioned people" (Interviewee 4, Manchester, employee).

"I would say that the creatives, there is a big gender split, so (...) across all departments are men, the men in the creative are very crude (...) sometimes you just think only you could get away with that because of who you are and the position you hold (...) it's male-dominated" (Interviewee 33, south of England, employee).

In other words, it appears that even though the progress has been made with equality policies, when it comes to the office culture the situation is somewhat different. Therefore, social interactions in the office tend to follow gendered patterns, except in cases when a creative director is a woman. For example, interviewee 2 stated that the advertising office is still a man's game and thus her social interactions are mostly with men, but she also stated that she can speak to her creative director about anything because conversations tend to go deeper with women, thus confirming both existing research in advertising of creative floors being masculine (Windels \& Lee, 2012; Grow and Broyles, 2011) and works from the Difference Approach showing gendered differences in social interactions and communication (West \& Zimmerman, 1983; Tannen, 1990; Merchant, 2012),

\footnotetext{
“Males I'd say. There are more creative male directors here, more male account managers I'd say. There is only actually... So at the minute there's probably between 10 and 15 creative directors here and only
} 
two of them are women, so it is definitely more a man's game here (...) I think maybe with women and the creative directors here you might feel a bit more... I do think I feel as if I could talk to them about anything differently. I guess it's just things might go a bit more in-depth with a woman" (London, manager).

There also seems to be gender segregation when it comes to interactions in the office with many interviewees stating they talk more with other women than men because they share information on their private lives with other women and talk about husbands, boyfriends and weekend activities. For example,

"I think women are more considerate. Men, they just say whatever they want to say (...)" (Interviewee 10, London, manager)

“...female, definitely (...) Well, in the past six years, I’ve started a family so it's definitely very much more family-orientated (...) I've felt when definitely speaking to a female they were more inclined to understand what I was talking about" (Interviewee 17, Leeds, employee).

However, several interviewees also mentioned a division of labour by saying that creative directors are mostly men whilst women tend to be in account handling, thus signalling that women are still occupying lower positions in the advertising world, which goes in line with latest data from UK Digital and Creative Sector Talent Insight Report (2017) that outlined that women form a majority of workforce but progress harder. For example,

"The creative floor, predominantly male. So we had about... And the digital floor actually. So you are talking out of 52 staff, about 30 of them were men, but the women were predominantly in the account management, project management and in the administration side of things" (Interviewee 26, Newcastle, manager).

This then has an impact on social interactions and conversations in the office due to the fact offices tend to be segregated by the position, however, as outlined above, sometimes offices end up in a masculine culture of banter and sexualisation of women regardless of whether men are the majority in that particular office. This culture leads to the situation that women report 
hearing sexist comments in their offices, and this particularly applies to women in senior positions where only two said they did not come across sexism. In this respect, interviewees report jokes about periods (Interviewee 26, Newcastle, manager), having to fight to stamp out the C-word from the office (Interviewee 14, London, manager) and some women stated they hear sexist comments "all the time. Every day" (Interviewee 30, London, employee). Some also stated that sexism is inherent to London and Oxford and that every single job place in those areas had an issue with sexism,

\footnotetext{
"In the current workplace, no. In previous workplaces, absolutely. All the time (...) There was, yes, definitely London, definitely Oxford. It's inherent. Every single agency that I have worked at, apart from this one, which is run by a husband and wife team, yes, there have definitely been sexist comments. Yes, absolutely, and inappropriate" (Interviewee 34, Reading, employee).
}

Besides, some interviewees reported sexual harassment in office parties,

“... There's definitely been a case within our agency where we've had HR issues where at a Christmas party, for example, people get a bit handy, often by very senior members of the team (...) A bit too close to ... too low down where your hands are. Yes, maybe a little bit too close for comfort" (Interviewee 38, London, employee).

The above situation where women listen to sexist comments in their offices or experience sexual harassment in office parties signals oppression and masculine character of advertising offices. As Bourdieu (2007) argued, sexual harassment is not always centred on sexual possession because, in some cases, it can also be centred on "sheer possession, the pure affirmation of domination in its pure state" (p. 21), which the example above demonstrates. 
The fact that the offices were historically seen as a man's world where women who were thinking they can succeed were seen as innocent and naïve (Savail, 2015) led to a question of whether interviewed women feel they had to work harder to prove themselves. This question was asked of women who hold managerial positions and of 20 interviewed women, 18 stated they feel they had to work harder than men to get promoted whilst some interviewees spoke of bias in favour of men where they only need to prove potential while women first need to prove themselves, thus signalling structural inequality and masculine habitus,

\footnotetext{
"The hard thing is men get promoted and offered opportunities based on the fact they have the potential to do it. I've always had to show that I can do it before I've gotten those opportunities if that makes sense" (London, manager).
}

Many women stated that the difficulty was also in being a single mother or they had to fight to attend meetings or present work, which can be linked to the devaluation of women in the workplace. As Bourdieu (2007) argued, "positions which become feminized are either already devalued (the majority of semi-skilled workers are women or immigrants) or declining, their devaluation being intensified, in a snowball effect, by the desertion of the men which it helped to induce" (p. 91), and since the advertising industry is feminised at the lower and middle level whilst men remain at the top, it opens a question whether women feel they have to work harder to obtain recognition in a masculine world. Many women in this study reported that they feel they had to work harder to succeed. For example,

\footnotetext{
"That's a difficult one for me. I think I have felt I had to work harder because I was a single parent, so I felt I had to work harder not just for me but other women as well” (Interviewee 5, Manchester, manager)
} 
"Not throughout my whole career but certainly in some scenarios in my career where (...) I've really had to fight tooth and nail to attend meetings or to present work back and I think part of that was because I was a female" (Interviewee 41, Leeds, manager)

Some also said they feel that men are better in pushing harder to get where they want to be, which brings about an issue of the organisational culture often centred on masculine ways of communication and behaviour (Crewe \& Wang, 2018; Vukoičić, 2013; Merchant, 2012; Rakow \& Nastasia, 2009; Acker, 1990; Tannen, 1990; West \& Zimmerman, 1983) as well as the feminist argument of organisations being masculine and thus oppressing women by depriving them of opportunities (Acker, 1990). In other words, communication research shows that women often communicate in a relationship-building way whereas men tend to be more direct and aggressive in their communication (Tannen, 1986; 1990; 1995; Yule, 2006), and in this study, women seem to be reporting that advertising offices are predominantly places for men and operate under masculine patriarchal structures, which also resonates with previous research in the field (Broyles \& Grow, 2008; 2010; Crewe \& Wang, 2018; Grow \& Broyles, 2011). Nevertheless, the responses from interviewees show that women indeed do things differently, in line with the Difference Approach (Vukoičić, 2013; Merchant, 2012; Rakow \& Nastasia, 2009; Acker, 1990; Tannen, 1990; West \& Zimmerman, 1983), however, they do not feel valued and they report organisational culture as man-dominated.

This leads to the question of promotions. Women who hold senior positions were asked how did they get promoted and how the process worked. Many stated they had to move around to get promoted, thus leading to a conclusion that women face a glass ceiling in organisations. For example, one interviewee stated that the fact she had to move jobs so often has caused her problems when interviewing for new jobs because she did not look serious enough and that she was having her career conditioned with not having another child, thus echoing views of Neil 
French, commonly considered a Godfather of creative advertising, who stated that women's work in advertising is 'crap' and that women cannot be committed to advertising work because they have children (Cadwalladr, 2005),

\footnotetext{
"I was moved around to move up. I think women have historically been promoted behind men in this industry. I think that's very common. I've heard way too many stories of that. So yes, absolutely. I've moved around to move up in my career a lot (...) I've had interviews and people question why I've only been in a place for two years. I had one role where my boss, he was a man and he said some inappropriate things about me being a woman, and not meaning to offend me but it was totally inappropriate. Told me to not have another baby so he could promote me in two years. That's a totally... It's something that you should go to HR about. But yes, things like that. So yes, it's not nice" (Interviewee 16, London, manager)
}

Therefore, it appears that the advertising offices are centred on masculinity and what seems central is that there is a masculine habitus in the advertising offices where men dominate social interactions and banter, whilst also engaging in sexism through the devaluation and discrimination of women. However, it also appears that there is a difference between men and women in regards to social interactions and banter, thus indicating that organisations are still a masculine habitus and that there are considerable differences between men and women and their social interactions. The final thematic graph based on this analysis would then mean that masculine habitus is constituted of differences between men and women, masculine domination in banter, masculine domination in social interactions and sexism (graph 2).

\section{Graph 2. The Final Thematic Analysis}




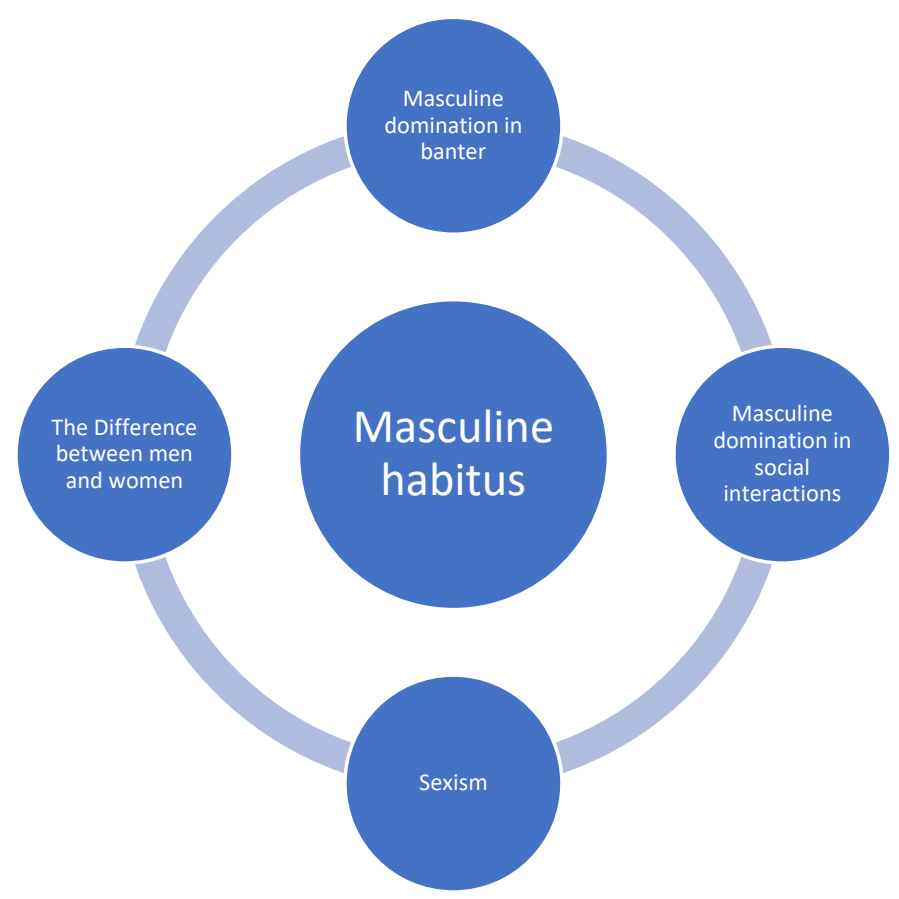

\section{Conclusion}

In conclusion, women reported meaningful differences in social interactions comparable to men, thus confirming findings from studies using the Difference Approach (West \& Zimmerman, 1983; Tannen, 1990; Merchant, 2012), where authors also argued that socialisation process between boys and girls influences communication and social interactions later in life. It seems that these differences spill over into the organisational world, and potentially causes structural inequality because organisations are, as many authors have argued a man's world (Saval, 2015; Acker, 1990; Bourdieu, 2007). Besides, women report that offices, where there are lots of men, tend to follow masculine norms and banter is predominantly masculine. Because of this, many women feel they do not fit in and that they work harder, which resonates with other works that argued that only 'blokish' women who embrace culturally masculine patterns can succeed (Mills, 2014; 2017; North, 2009; Topić, 2018; 2020). Therefore, organisations can be seen as masculine habitus because apart from these differences between men and women, women also reported that they feel they have to work harder and prove themselves before they obtain recognition whereas men advance because they are men 
and thus are given a benefit of the doubt. Nevertheless, women report devaluation, sexism and harassment.

Whilst this was a qualitative study based on interviews with 38 women in England, the findings signal structural inequality and the need for consciousness-raising because whilst women recognised inequality when directly asked whether they feel they had to work harder to succeed, women generally do not complain about banter and social interactions and do not say this is what oppresses them and creates masculine habitus in which it is very hard for a woman to succeed. For example, women reported gendered segregation in positions with creative directors being mostly men, however, they did not link this situation with office culture and said that something needs to change in the way employees interact at work, which then leads to bonding and career progressions. Bourdieu's (2007) argued that individuals rarely challenge injustice or oppression because inequality is embodied to the system to an extent that people fail to recognise inequality due to processes and practices being an everyday thing (Bourdieu and Wacquant, 1992; Bourdieu, 2007; Chambers, 2005).

Therefore, consciousness-raising is needed to make women aware that inequality is more than just a pay gap and glass ceiling, but also the structure of the organisation that results with pay gap, discrimination of mothers and patriarchal culture in which women are not valued as much as men. As Bourdieu (2007) argued, inequality perpetuates itself through everyday practices to the point this inequality becomes "acceptable and even natural" and this practice can be seen as "symbolic violence, a gentle violence, imperceptible and invisible even to its victims" (p. 1). Therefore, societies work as masculine habitus grounded in "arbitrary division which underlines both reality and the representation of reality" (ibid, p. 3). Therefore, "we have embodied the historical structures of the masculine order in the form of unconscious schemes 
of perception and appreciation" (Bourdieu, 2007, p. 5), and this is because mechanisms of domination are incorporated into daily realities so the social order functions as "an immense symbolic machine tending to ratify the masculine domination on which it is founded: it is the sexual division of labour, a very strict distribution of the activities assigned to each sex, of their place, time and instruments; it is the structure of space, with the opposition between the place of assembly or the market, reserved for men, and the house, reserved for women" (Bourdieu, 2007, p. 9-11).

The oppression based on this research study, and other available research on women in advertising (Broyles \& Grow, 2010; 2008; Grow \& Broyles, 2008; Crewe \& Wang, 2018; Topić, 2020; Gregory, 2009), signals that the oppression is structural and embedded into organisations that still function as a masculine world. Therefore, consciousness-raising is needed to make women aware of structural and organisational issues that led to oppression and the fact that they are socialised differently, and consequentially do things differently, does not mean they should be devalued because they do not fit into culturally masculine work expectations.

Future research should look into women networks and how networking events could be used for consciousness-raising. Whilst some works explore this issue, these are mostly situated in the 1980s and the 1990s (Gregory, 2016) or they explore networking in other industries (McCarthy, 2004), however, there is evidence that networking and connecting with others improves overall wellbeing as well as career progression (Achor, 2018). Therefore, more research and activism are needed in this area (especially in advertising) to extend networking for creating opportunities in a man-dominated world and make women recognise what constitutes oppression to raise consciousness and entice changes in the workplace. 


\section{References}

Achor, S. (2018), “Do Women's Networking Events Move the Needle on Equality?”, Harvard Business Review, 13 February, retrieved from https://hbr.org/2018/02/do-womens-networkingevents-move-the-needle-on-equality

Acker, J. (1990), "Hierarchies, jobs, bodies: A Theory of Gendered Organizations", Gender \& Society Vol. 4 No. 2, pp. 139-158.

Alvesson, M. (2013), Understanding Organisational Culture, 2nd edition, London, SAGE.

Alvesson, M. (1998), “Gender Relations and Identity at Work: A Case Study of Masculinities and Femininities in an Advertising Agency", Human Relations Vol. 51 No. 8, pp. 969-1005.

Bourdieu, P. (2007), Masculine Domination, Cambridge, Polity Press.

Bourdieu, P. and Wacquant, L. (1992), An Invitation to Reflexive Sociology, Cambridge, Polity Press.

Braun, V. and Clarke, V. (2006), "Using thematic analysis in psychology", Qualitative Research in Psychology, Vol. 3 No. 2, pp. 77-101.

Broyles, S. L. and Grow, J. (2010), "Waving Your Way Through the Creative Labyrinth: Words of Wisdom from Professionals", Proceedings of the 2010 American Academy of $\begin{array}{lllll}\text { Advertising, } & \text { Lee, } & \text { W.-N } & \text { (ed), } & \text { retrieved }\end{array}$ https://www.researchgate.net/publication/277013151 Weaving Your Way Through the Cr eative_Labyrinth_Words_of_Wisdom_from_Professionals

Broyles, S.L. and Grow, J.M. (2008), “Creative Women in Advertising Agencies: Why So Few “Babes in Boyland"?” Journal of Consumer Marketing Vol. 25 No. 1, pp. 4-6. Retrieved from 
https://epublications.marquette.edu/cgi/viewcontent.cgi?referer=https://www.google.com/\&ht tpsredir=1\&article=1021\&context $=$ comm_fac\&sei-redir=1 $($ accessed 29 December 2019)

Cadwalladr, C. (2005), “This advertising boss thinks women make 'crap' executives. It seems he's not alone", The Guardian, 23 October, retrieved https://www.theguardian.com/media/2005/oct/23/advertising.genderissues

Chambers, C. (2005), "Masculine domination, radical feminism and change", Feminist Theory Vol. 6 No. 3, pp. 325-346.

CIPR (2019), "State of the Profession 2019", retrieved from https://www.cipr.co.uk/sites/default/files/11812\%20State\%20of\%20Profession v12.pdf (accessed 29 December 2019).

Clare, K. (2013), "The essential role of place within the creative industries: Boundaries, networks and play", Cities Vol. 34, pp. 52-57.

Cooke, R. (2019), “Sexism in advertising: 'They talk about diversity, but they don't want to change",, The Guardian, 14 April, retrieved from https://www.theguardian.com/media/2019/apr/14/sexism-in-advertising-industry-gender-paygap-diversity

Creswell, J.W. (2007), Qualitative Inquiry and Research Design: Choosing among Five Approaches, Thousand Oaks, CA: Sage.

Crewe, L. and Wang, A. (2018), "Gender inequalities in the City of London advertising industry", Environment and Planning A: Economy and Space Vol 50 No 3, pp. 671-688.

Davies, R. and Jackson, J. (2016), "Saatchi \& Saatchi boss resigns amid sexism row", The Guardian, 3 August, retrieved from https://www.theguardian.com/media/2016/aug/03/saatchisaatchi-boss-kevin-roberts-resigns-amid-sexism-row (accessed 17 May 2019) 
Daymon, C. and Demetrious, K. (2010), “Gender and public relations: Perspectives, applications and questions", PRism Vol 7 No 4, retrieved from $\underline{\text { http://citeseerx.ist.psu.edu/viewdoc/download?doi=10.1.1.669.5010\&rep=rep1\&type=pdf }}$ (accessed 29 December 2019)

Disch, L.J. and Hawkesworth, M. (2016), The Oxford Handbook of Feminist Theory, Oxford: Oxford University Press.

French, M. (1985), Beyond Power: On Women, Men and Morals, New York: Ballantine.

Gill, R. (2014), “Unspeakable inequalities: Post-feminism, entrepreneurial subjectivity and the repudiation of sexism among cultural workers", Social Politics Vol. 21 No. 4, pp. 509-528.

Grabher, G. (2004), "Learning in projects, remembering in networks? Communality, sociality, and connectivity in project ecologies", European Urban and Regional Studies Vol. 11 No. 2, pp. $103-123$.

Gregory, M. R. (2016), The Face of the Firm: Corporate Hegemonic Masculinity at Work, London: Routledge.

Gregory, M. R. (2009), "Inside the Locker Room: Male Homosociability in the Advertising Industry", Gender, Work \& Organization, Vol. 16 No. 3, pp. 323-347.

Grow, J.M. and Yang, S. (2018), "Generation-Z Enters the Advertising Workplace: Expectations Through a Gendered Lens", Journal of Advertising Education Vol. 22 No. 1, pp. $7-22$.

Grow, J. and Broyles, S. L. (2008), "Unspoken Rules of the Creative Game: Insights to Shape the Next Generation from Top Advertising Creative Women", Advertising \& Society Review, retrieved from 
https://www.researchgate.net/publication/236807146 Unspoken Rules of the Creative Ga me Insights to Shape the Next_Generation from_Top_Advertising Creative Women

Hemming, H. (1985), “Women in a Man's World: Sexual Harassment”, Human relations Vol. 38 No. 1, pp. 67-79.

IPA Agency Census (2019), “IPA publishes 2019 IPA Agency Census”, retrieved from https://ipa.co.uk/news/agency-census-2019

IPA website (n.d.), "Why choose an IPA Agency?", retrieved from https://ipa.co.uk/membership/why-choose-an-ipa-member-agency/

Jaggar, A. and Rothenberg, P. (eds.) (1994), Feminist frameworks, New York, McGraw-Hill. Jarvis, H. and Pratt, A.C. (2006), "Bringing it all back home: The extensification and 'overflowing' of work: The case of San Francisco's new media households", Geoforum Vol. 37 No. 3, pp. 331-339.

Kanter, R. (1977), Men and women of the corporation, New York, Basic Books.

Kemp, L.J. (2016), ““Trapped' by metaphors for organizations: Thinking and seeing women's equality and inequality", Human relations Vol. 69 No. 4, pp. 975-1000.

Kvale, S. and Brinkmann, S. (2009), Interviews (2nd edition), Thousand Oaks, CA: Sage.

Lapadat, J. (2010), “Thematic analysis”, In - Mills, A. J.; Durepos, G., \& Wiebe, E. (eds), Encyclopedia of case study research, Thousand Oaks: Sage (pp. 926-928).

Lewis, P. (2014), "Postfeminism, femininities and organization studies: Exploring a new agenda", Organizational Studies Vol. 35, No. 12, pp. 1845-1866.

MacKinnon, C. (1989), Toward a Feminist Theory of the Sate. Cambridge, MA, Harvard University Press. 
Maltz, Daniel N. and Borker, R.A. (1982), “A cultural approach to male-female miscommunication", in - Gumperz, J J (ed.) Studies in Interactional Sociolinguistics 2. Cambridge: Cambridge University Press.

McCarthy, H. (2004), Girlfriends in High Places, London: Demos.

Merchant, K. (2012), "How Men and Women Differ: Gender Differences in Communication Styles, Influence Tactics, and Leadership Styles", CMS Senior Theses, Paper 513, retrieved from http://scholarship.claremont.edu/cgi/viewcontent.cgi?article $=1521 \&$ context $=\mathrm{cmc}$ theses (accessed 31 May 2019)

McLeod, C., O’Donohoe, S. and Townley, B. (2011), "Pot noodles, placements and peer regard: creative career trajectories and communities of practice in the British advertising industry", British Journal of Management Vol. 22 No. 1, pp. 114-131.

Mills, E. (2017), “How to Deal with Men”, British Journalism Review, Vol. 28 No. 4, pp. 5-7. Mills, E. (2014), “Why Do the Best Jobs Go to Men?”, British Journalism Review, Vol. 25 No. (3), pp. 17-23.

Morse, J. M. and Richards, L. (2002), Readme First for a User's Guide to Qualitative Methods, Thousand Oaks, London, New Delhi, Sage.

Nixon, S. (2013), Advertising Cultures: Gender, Commerce, Creativity, London, SAGE.

North, L. (2009), The Gendered Newsroom: How Journalists Experience the Changing World of Media, Cresskill, NJ: Hampton Press.

Pateman, C. (1988), The Sexual Contract, Stanford, Stanford University Press. 
Place, K.R. and Vaderman-Winter, J. (2018), "Where are the women? An examination of research on women and leadership in public relations", Public Relations Review Vol. 44 No. 1, pp. 165-173.

Rakow, L.F. and Nastasia, D.I. (2009), "Feminist Theory of Public Relations: An Example from Dorothy E. Smith", in - Oyvind, I, van Ruler, B and Frederiksoon, M (eds.) Public Relations and Social Theory. London: Routledge.

Santos, C. and Garibaldi de Hilal, A.V. (2018), "Same, same but different? Women's experiences with gender inequality in Brazil”, Employee Relations Vol. 40 No. 3, pp. 486-499.

Saval, N. (2015), Cubed: A Secret History of the Workplace, New York, Anchor Books.

Simpson, R. (1997), "Have Times Changed? Career Barriers and the Token Woman Manager", British Journal of Management Vol. 8, pp. 121-130.

Sleeman, C. (2019), "The creative industries' gender equality secret has been exposed by big data", World Economic Forum, retrieved from https://www.weforum.org/agenda/2019/08/gender-equality-secret-exposed-by-big-data/ (accessed 29 December 2019)

Stein, L. (2017), “Advertising is Still a Boy's Club", AdAge 31 May, retrieved from https://adage.com/article/news/advertising-a-boy-s-club/309166 (accessed 29 December 2019).

Sweney, M. (2019), "First ads banned for contravening UK gender stereotyping rules", The Guardian, 14 August, retrieved from https://www.theguardian.com/media/2019/aug/14/firstads-banned-for-contravening-gender-stereotyping-rules (accessed 29 December 2019)

Tannen, D. (1995), “The Power of Talk: Who Gets Heard and Why", Harvard Business Review, September-October, pp. 139-149. 
Tannen, D. (1990), You Just Don't Understand, New York, Penguin Random House.

Tannen, D. (1986), That's Not What I Meant! New York, Penguin Random House.

Templin, C. (1999). "Hillary Clinton as threat to gender norms: Cartoon images of the first lady”, Journal of Communication Inquiry, Vol. 23 No. 1, pp. 20-36.

Topić, M. (2020), “Two Englands? Blokishness, Masculine Habitus and the North-South Divide in the Advertising Industry", Gender in Management: An International Journal. EarlyCite: $\quad$ https:/www.emerald.com/insight/content/doi/10.1108/GM-12-2019$\underline{0263 / \mathrm{full} / \mathrm{html}}$

Topić, M. (2018), "Not bloke-ified enough? Women journalists, supermarket industry and the debate on sugar in the British press (2010-2015)", The Newspaper Research Journal Vol. 39 No. 4, pp. 433-442.

UK Digital and Creative Sector Talent Insight Report (2017), retrieved from https://dma.org.uk/uploads/ckeditor/UK_Digital_and_Creative_Sector_Report.pdf (accessed 17 May 2019).

Vukoičić, J. (2013), "Radical feminism as a discourse in the theory of conflict", Sociological discourse Vol. 3 No. 5, pp. 49.

West, C. and Zimmerman, D.H. (1983), "Small insults: A study of interruptions in conversations between unacquainted persons", in - Thorne, B, Kramerac, C and Henley, N (eds.) Language, gender and society, Rowley, Newbury House.

Windels, K. and Lee, W.N. (2012), “The construction of gender and creativity in advertising creative departments", Gender in Management: An International Journal, Vol. 27 No. 8, pp. $502-519$.

Yule, G. (2006), The Study of Language, Cambridge, Cambridge University Press. 